\title{
Failure Propensity of Austenitic Stainless Steels by Chloride Induced Stress Corrosion Cracking in Air *
}

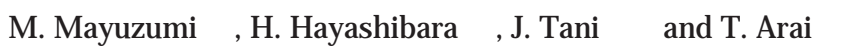 \\ ** Tokyo Institute of Technology \\ *** Central Research Institute of Electric Power Industry
}

\begin{abstract}
Chlorides induced stress corrosion cracking (ESCC) behavior was examined for SUS304L, SUS316L and SUS304 stainless steels (SS) after depositing synthetic sea water simulating sea salt particles at a temperature range from $333 \mathrm{~K}$ to $353 \mathrm{~K}$ with relative humidity of $35 \%$. A stress-ESCC failure time relationship was formulated for SUS304L SS as $\sigma=-A \log \left(t_{f}\right)+B$, whereo : applied stress $(\mathrm{M} \mathrm{Pa}), \mathrm{t}_{\mathrm{f}}$ : time to failure $(\mathrm{h}), \mathrm{A}=23.7 \mathrm{~T}-7020, \mathrm{~B}=43.7 \mathrm{~T}-11600, \mathrm{~T}$ : absolute temperature $(K)$. Even an incipient micro-crack was not observed on the specimen surface of the SS at the applied stress level of $0.25 \sigma_{y}\left(\sigma_{y}: 0.2 \%\right.$ proof stress $)$, although SCC initiated at the applied stress level of $0.5 \sigma_{y}$. Thus the threshold stress should be between $0.5 \sigma_{y}$ and $0.25 \sigma_{y}$ for these SS, and the threshold stress would rise beyond these values if the stress concentration be considered at the bottom and circumference of a pit. A statistical analysis suggested that the ESCC crack length and crack depth conformed to the double exponential distribution.
\end{abstract}

Key words : stainless steel, ESCC, chlorides, sea salt particle, relative humidity

\section{Introduction}

Stainless steels are widely used as structural materials for chemical plants, nuclear power plants, etc, because of the superior general corrosion resistance, mechanical properties, heat resistance, and weldability ${ }^{1)}$. However, it is well known that austenitic stainless steels are susceptible to stress corrosion cracking (SCC) in certain environments under tensile stress. SCC induced by chlorides, such as sea salt particles, for example, is observed on various components in chemical plants ${ }^{2)}, 3$, and also on piping of a nuclear power plant ${ }^{4)}$ built in the coastal area. This type of SCC is called as external SCC (ESCC) or atmospheric SCC since the cracking starts from out side of the equipment in air ${ }^{2}$, 3).

ESCC manifests itself as inter-granular cracking or trans-granular cracking depending on relative humidity, material condition, such as sensitized or not, and temperature. Inter-granular SCC (IGSCC) was usually observed in sensitized parts of stainless steel components at around ambient temperature. On the other hand, trans-granular SCC (TGSCC) observed regardless of the material conditions at relatively high temperature $>323 \mathrm{~K}$. For the environmental condition, a certain degree of relative humidity $(\mathrm{RH})$ is necessary to moisten the chlorides adhered on the stainless steel surface. The RH for ESCC easy to $\operatorname{occur}(\mathrm{RH} p)$ is dependent on the type of chlorides. Thus the RHp of $\mathrm{NaCl}$, for example, is $60 \%$ and that of $\mathrm{M} \mathrm{gCl}_{2}$ is $30 \%$ according to Shoji et al .5) Another important factor of ESCC is the residual tensile stress derived from the welding or cold working processes. Hence, ESCC was usually observed at the weld joints or geometrical disconti-

* 第51回材料と環境討論会 (名古屋, 2004年) で一部発表

** 2-12-1, 0-okayama, M eguro-ku, Tokyo, 152-8552 J apan

*** 2-6-1, N agasaka, Yokosuka-shi, Kanagawa-ken, 240-0196 J apan nuities.

To prevent premature failures of equipment caused by ESCC of stainless steels, it is necessary to clarify the stress-ESCC failure time relationships after considering the probabilistic aspect of ESCC phenomena, and the environmental conditions which lead to occurrence of ESCC in the stainless steel equipment. Hence, the purposes of this study are to obtain the stress-ESCC failure time relationship for SUS304L stainless steel, and also to make a statistical analysis on ESCC crack size distribution.

\section{Experimental}

\subsection{Material}

Austenitic stainless steel (SS) plates, SUS304L (304L), SUS316L (316L) and SUS304 (304), were examined in this study, since these SS are widely used as the structural materials for chemical plants and also nuclear power plants. Table 1 shows chemical composition of the test materials. Tensile specimens with a gage section of $2.0 \mathrm{~mm}$ thick, $5.0 \mathrm{~mm}$ wide, and $30 \mathrm{~mm}$ long were machined from the plate materials. After machining, the specimen was polished by emery papers to \# 600 , degreased with acetone, rinsed with de-ionized water, and then attached to a loading apparatus that uses a spring to apply stress. Some specimens from 304L SS were aged at $923 \mathrm{~K}$ to simulate the heat history during welding process.

\subsection{Test procedure}

Stress-ESCC failure tests were conducted on 304L and $316 \mathrm{~L}$ SS by a constant load method using a spring for load-

Table 1 Chemical composition of specimen.

\begin{tabular}{|c|c|c|c|c|c|c|c|c|}
\hline & $\mathrm{C}$ & $\mathrm{Si}$ & $\mathrm{Mn}$ & $\mathrm{P}$ & $\mathrm{S}$ & $\mathrm{Ni}$ & $\mathrm{Cr}$ & $\mathrm{Mo}$ \\
\hline SUS304L & 0.020 & 0.67 & 1.34 & 0.032 & 0.002 & 9.69 & 18.13 & - \\
\hline SUS316L & 0.019 & 0.65 & 1.23 & 0.034 & 0.002 & 12.07 & 17.51 & 2.08 \\
\hline SUS304 & 0.06 & 0.61 & 0.95 & 0.028 & 0.011 & 8.12 & 18.10 & - \\
\hline
\end{tabular}


ing ${ }^{6)}$. Applied stress $\left(\sigma_{\text {ap }}\right)$ ranges from $0.25 \sigma_{y}$ to $1.75 \sigma_{y}$ of the SS (whereo $\sigma_{y}: 0.2 \%$ proof stress). To deposit chlorides simulating sea salt particles on the gage section of the specimen, droplets $(10 \mu \mathrm{L}$ each) of synthetic sea water were put on the gage section by a micro-pipette and dried. The resultant surface chlorine concentration was higher than $10 \mathrm{~g} / \mathrm{m}^{2}$ as $\mathrm{Cl}$. The loading apparatus with the specimen was placed in a constant temperature and humidity chamber kept at test temperatures from $333 \mathrm{~K}$ to $353 \mathrm{~K}$ with $\mathrm{RH}=35 \%$ after chloride deposition for the test to obtain the stress-failure time relationships of 304L SS and $316 \mathrm{~L}$ SS. $\mathrm{RH}=35 \%$ was selected for the test condition since $\mathrm{RH}=35 \%$ was the most aggressive environment to the SS contaminated with sea salt particles ${ }^{5)}$. After ESCC tests, the surface of some specimens was observed by scanning electron microscopy (SEM) to determine the cracking or corrosion morphologies and also the threshold stress of ESCC at the test condition.

In addition, 10 specimens of 304 SS were tested under the environmental condition of $353 \mathrm{~K}$ with $\mathrm{RH}=35 \%$ after applying the stress of $\sigma_{y}(300 \mathrm{MPa})$ to examine the probabilistic aspect of ESCC. The test time was set up to $260 \mathrm{~h}$ so as to avoid decrease in the applied stress by a large displacement of the spring because of the elongation of the specimen at the cracked region. The droplets of synthetic sea water were put on 2 or 3 points in the gage section in this case. After exposure to the environment, the crack length and depth were measured by SEM after revealing the maximum ESCC fracture surface at each chloride spot.

A relatively short term test (interrupting ESCC test) also was done to estimate the time when incipient cracks initiated. The test environment was the same as mentioned above, and the test times were set to $3 \mathrm{~h}, 5 \mathrm{~h}, 10 \mathrm{~h}$ and 20 h. After the test, the specimen surface was observed carefully by SEM to examine the corrosion morphology at each exposure time.

\section{Results and Discussion}

\subsection{Stress-ESCC failure time relationship}

Fig. 1 shows the relationship between applied stress and failure time for $304 \mathrm{~L}$ SS obtained at temperature of $343 \mathrm{~K}$ with relative humidity of $35 \%$. The failure time changed dependent on the applied stress, the larger the applied stress the smaller the failure time. For example, failure times of $410 \mathrm{~h}$ and $700 \mathrm{~h}$ were obtained for the applied stress of $475 \mathrm{MPa}$ and $200 \mathrm{MPa}$, respectively. The aged specimens showed a tendency to fail in smaller time than the as received specimens in this particular test temperature. However, such a tendency was not observed in the test results at $353 \mathrm{~K}^{6}$ ) and the effect of sensitization was not expected from the carbon content of $0.02 \%$. Thus it was concluded that there was no difference in ESCC susceptibility for 304L SS with as received or aged conditions.

In general, a stress-failure time relationship was expressed as the following equation ${ }^{7)}$ for the applied stress

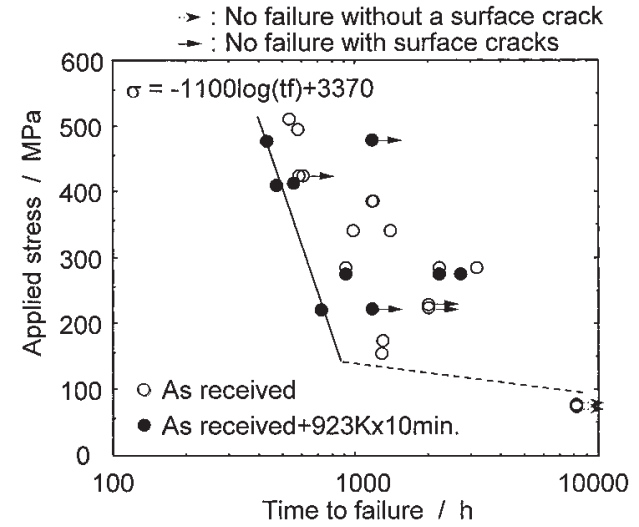

Fig. 1 Effect of the applied stress on the ESCC failure time of $304 \mathrm{~L}$ SS under the test condition of $\mathrm{RH}=35 \%$ at $343 \mathrm{~K}$.

larger than the threshold stress at a given temperature ;

$$
\sigma=-A \log \left(t_{f}\right)+B \text {, }
$$

whereo : applied stress (M Pa), $t_{f}$ : time to failure (h). Equation (1) can be derived after the assumptions of a) the failure time $\left(\mathrm{t}_{\mathrm{f}}\right)$ being equal to the incubation time $\left(\mathrm{t}_{\mathrm{i}}\right)$ in a constant load SCC test, and $b$ ) the incubation time $\left(t_{i}\right)$ being described by the Arrhenius type equation. By applying equation (1) to the minimum failure time for each applied stress in the test results at $353 \mathrm{~K}^{6}$ ) and $343 \mathrm{~K}$, the following two stress-failure time relationships can be obtained ;

$$
\begin{aligned}
& \sigma=-1340 \log \left(\mathrm{t}_{\mathrm{f}}\right)+3810(\text { at } 353 \mathrm{~K}), \\
& \sigma=-1100 \log \left(\mathrm{t}_{\mathrm{f}}\right)+3370(\text { at } 343 \mathrm{~K}) .
\end{aligned}
$$

Thus we can obtain temperature dependency of the constants, $A$ and $B$, as follows ;

$$
\begin{aligned}
& A=23.7 T-7020, \\
& B=43.7 T-11600 .
\end{aligned}
$$

Although the above treatment is an expedient one, the following estimation can be made for the stress-failure time relationship at $333 \mathrm{~K}$;

$$
\sigma=-865 \log \left(t_{f}\right)+2930
$$

The stress-failure time relationship calculated from equation (6) was plotted in Fig. 2 as a solid line, together with the experimental data of $304 \mathrm{~L}$ SS. The predicted failure times coincided moderately with the corresponding experi-

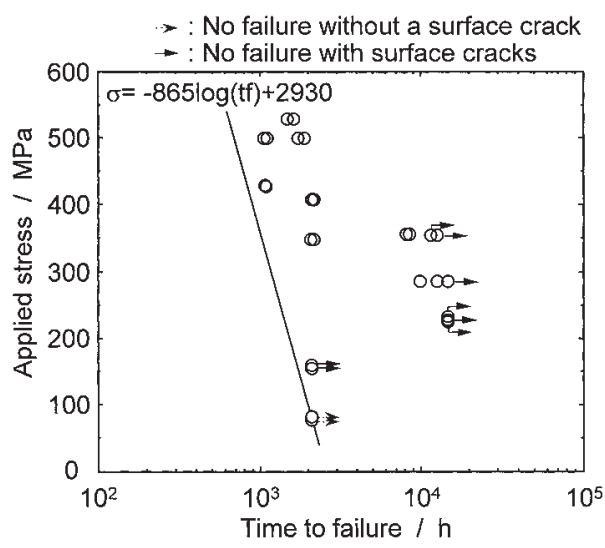

Fig. 2 Effect of the applied stress on the ESCC failure time of $304 \mathrm{~L}$ SS under the test condition of $\mathrm{RH}=35 \%$ at $333 \mathrm{~K}$. The solid line shows the estimated failure time. 


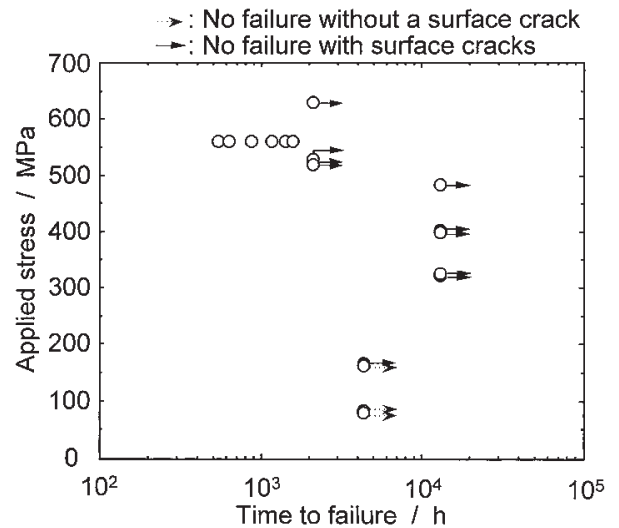

Fig. 3 Effect of the applied stress on the ESCC failure time of $316 \mathrm{~L}$ SS under the test condition of $\mathrm{RH}=35 \%$ at $353 \mathrm{~K}$.

mental values for the higher applied stress region, although further analysis should be done to improve the applicability to the lower applied stress region.

Stress-ESCC failure test also was done on 316L SS having a higher resistance to pitting corrosion due to chlorides owing to Mo addition. Fig. 3 shows the applied stress-failure time relationship for 316 LS obtained at 353 $\mathrm{K}$ with $\mathrm{RH}=35 \%$. ESCC failure was observed only on the applied stress of $1.5 \sigma_{y}$. The minimum failure time was 533 $\mathrm{h}$ for the applied stress of $560 \mathrm{MPa}$ in contrast to the minimum failure time of $242 \mathrm{~h}$ for $304 \mathrm{~L}$ SS with the applied stress of $496 \mathrm{MPa}$ at the same environmental condition. Thus 316L SS had a higher resistance to ESCC than 304L SS. This test result is in a good accordance with an electrochemical study showing 316L SS had a higher pitting potential than $304 \mathrm{~L}$ SS in saturated synthetic sea water at a temperature region of $303 \mathrm{~K}$ to $353 \mathrm{~K}^{8}$ ).

\subsection{Threshold stress for ESCC}

It is well known that a threshold stress, under which SCC does not occur or SCC failure time increases remarkably, appears on an applied stress-failure time relationship ${ }^{7)}$. Usually, a threshold stress is dependent on the combination of materials and corrosion environments. A very low threshold stress will be expected for ESCC from the field data ${ }^{9)}$ showing ESCC of the piping without weld joints or any geometrical discontinuities nearby. There is few experimental data available ${ }^{10)}$ at present for the threshold stress of ESCC for SS in air. In this study, no visible crack was observed on the specimen surface for the applied stress of $0.25 \sigma_{y}(78 \mathrm{M} \mathrm{Pa})$ as shown in Figs. 1 and 2 (dashed arrow). Hence, the specimen surface was observed carefully by SEM for a micro-crack after removing corrosion products. Fig. 4 shows the surface appearance of the specimens after the tests at (a) $343 \mathrm{~K}$ for $8127 \mathrm{~h}$, and (b) $333 \mathrm{~K}$ for $2089 \mathrm{~h}$ with the applied stress of $0.25 \sigma_{y}$. No evidence of SCC cracks was found on the corroded region of 304L SS at both the test temperatures. The same results were obtained for $304 \mathrm{SS}$ and aged $304 \mathrm{~L}$ SS at $353 \mathrm{~K}^{6}$ ), and also for $316 \mathrm{~L}$ SS tested at $353 \mathrm{~K}$ as shown in Fig. 3 (dashed

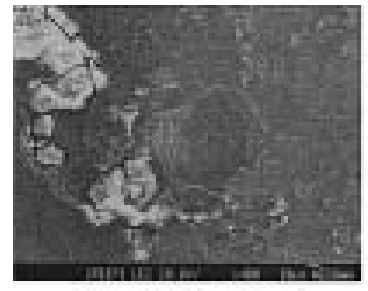

(a) $343 \mathrm{~K}$ for $8127 \mathrm{~h}$

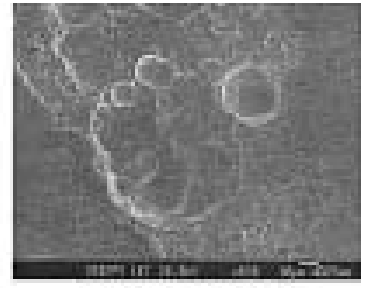

(b) $333 \mathrm{~K}$ for $2089 \mathrm{~h}$
Fig. 4 Surface appearance of 304L SS after exposure to the test environments of $\mathrm{RH}=35 \%$ at (a) $343 \mathrm{~K}$ for $8127 \mathrm{~h}$, and (b) $333 \mathrm{~K}$ for $2089 \mathrm{~h}$.

arrow). Thus it can be concluded that the threshold stress of ESCC is as high as $0.25 \sigma_{y}(78 \mathrm{M} \mathrm{Pa}$ and $85 \mathrm{M} \mathrm{Pa}$ for $304 \mathrm{~L}$ SS and $316 \mathrm{~L}$ SS, respectively) for these SS at the temperature region of less than $353 \mathrm{~K}$. The threshold stress was almost the same as that reported by Takemoto, et al. ${ }^{10)}$ for 304 SS. When a sensitization treatment was applied, 304 SS was failed for $403 \mathrm{~h}$ at the applied stress of $0.25 \sigma_{y}$, although the fracture surface showed entirely trans-granular cracking ${ }^{6)}$. Thus further studies will be necessary to determine the threshold stress for ESCC of sensitized parts, as weld joints, of SS.

Pitting corrosion only was observed on the corroded area as shown in Fig. 4. The actual threshold stress might be larger than the value discussed above, since the corrosion pit will be expected to act as a stress concentration site. Stress concentration factors of 2.23 and $1.75^{11)}$ are calculated at the circumference and the bottom of a pit, respectively, when a semi-spherical shape of the pit was assumed together with the Poisson's ratio of 0.25 . Thus the threshold stress would increase at least to $0.56 \sigma_{y}$ or $0.44 \sigma_{y}$ if ESCC initiated from a smooth surface without the accelerating contribution of pitting corrosion.

\subsection{Statistical analysis on ESCC}

SCC essentially has a probabilistic aspect and, hence, a statistical analysis ${ }^{12)}$ was made on the ESCC crack length and the crack depth. The crack lengths and the crack depths we obtained for 304 SS were the maximum values at each chloride spot on the gage section. Hence the double exponential distribution was applied to the crack lengths and the crack depths, since Akashi et al. suggested that the distribution of the maximum crack depths of IGSCC could conform to both the normal probability distribution and the double exponential distribution ${ }^{13)}$. Fig. 5 shows the double exponential distribution plot for the crack length (a) and the crack depth (b) both divided by the test time ( $261 \mathrm{~h}$ or $162 \mathrm{~h}$ ). It is obvious from the linearity of the plots that both the crack length and the crack depth conformed to the double exponential distribution, although two data from the crack lengths showed a relatively large deviation from the straight line. Fig. 6 shows the fracture surface of the specimen with the crack deviating from the double exponential plots. It was suggested that the fracture surface was produced through a macro- 


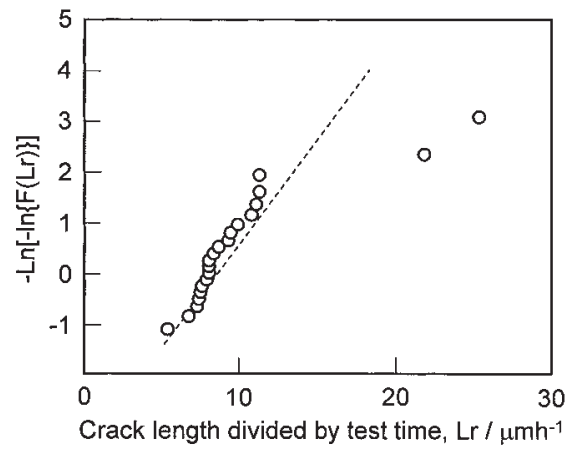

(a) Crack length

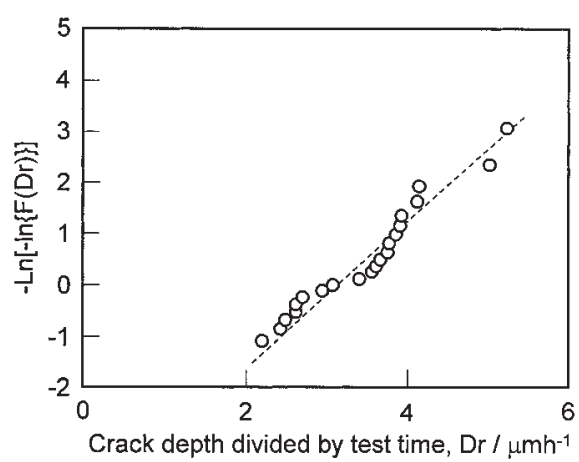

(b) Crack depth

Fig. 5 The double exponential distribution plot for (a) the ESCC crack length on the specimen surface and (b) the crack depth.

scopic coalition of two cracks into one larger crack, as shown in the line on the Fig. The same tendency was observed also on the fracture surface of the other one specimen. Thus the deviation of the two data in Fig. 5 (a) would have been caused by the macroscopic crack coalition and the resultant abrupt increase in the crack length on the specimen surface.

As mentioned above, both the ESCC crack length and the crack depth conformed to the double exponential distribution. One prerequisite for SCC phenomena to fit the distribution would be that the SCC process is dominated by either of the crack initiation sub-process or the crack propagation sub-process, and the time necessary to reach a certain crack length or crack depth is determined by one of the sub-processes ${ }^{12)}$. To examine which of the subprocess controls the entire ESCC process in this test condition, the interrupting ESCC test was conducted for $3 \mathrm{~h}$ through $20 \mathrm{~h}$ at $353 \mathrm{~K}$ with $\mathrm{RH}=35 \%$, and the corroded surfaces were observed by SEM for incipient cracks. Fig. 7 (a) and 7 (b) shows the surface appearance of the specimens tested for $3 \mathrm{~h}$ and $5 \mathrm{~h}$, respectively. It is obvious from the Fig. that ESCC initiated only after $3 \mathrm{~h}$ or $5 \mathrm{~h}$ of exposure to the environment and, thus, the crack propagation sub-process occupied almost all of the test durations of 261 $\mathrm{h}$ or $162 \mathrm{~h}$. Thus the crack propagation sub-process determined the crack size in this study. However, this result could be obtained since both the surface chlorine concentration and the environmental condition were severe

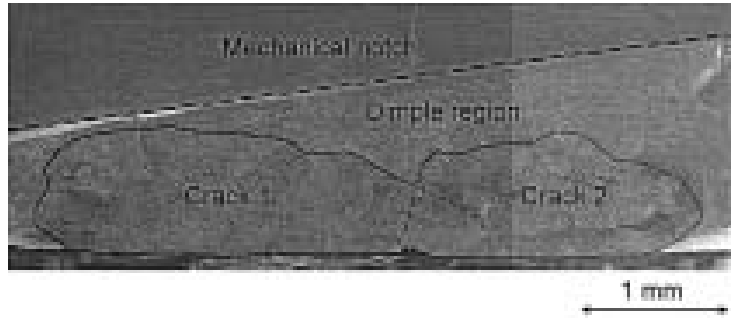

Fig. 6 ESCC failure surface showing the coalition of two cracks into one larger crack.

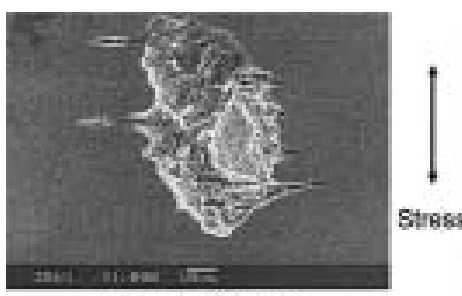

(a) Test time: $3 \mathrm{~h}$

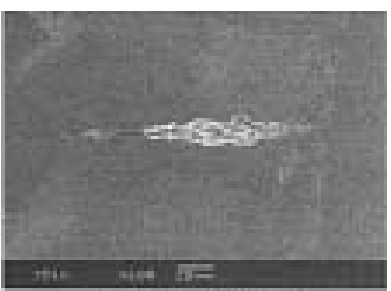

(B) Test time: $5 \mathrm{~h}$
Fig. 7 Surface appearance of the specimens tested for (a) $3 \mathrm{~h}$ and (b) $5 \mathrm{~h}$ at $353 \mathrm{~K}$ with $\mathrm{RH}=35 \%$ (applied stress $: \sigma_{\mathrm{y}}$ ).

enough for 304 SS to cause ESCC within a very short exposure time. In actual components, however, the time for the crack initiation sub-process or the incubation time would be almost equal to the time necessary to contaminate the SS component surface by chlorides beyond the critical surface chlorine concentration ${ }^{14)}$, and determine the failure time of the components by ESCC.

\section{Conclusions}

(1) A stress-failure time relationship was formulated for SUS304L SS as $\sigma[\mathrm{MPa}]=-A \log \left(\mathrm{t}_{\mathrm{f}}[\mathrm{h}]\right)+B$, where $A=23.7 T-7020$ and $B=43.7 T-11600$, in the temperature range between $333 \mathrm{~K}$ and $353 \mathrm{~K}$. SUS316L SS had a higher resistance to ESCC than SUS304L SS.

(2) Even an incipient micro-crack was not observed on SUS304L SS and SUS316L SS surface for an applied stresS level of $0.25 \sigma_{y}$ after exposure to the test environment of $\mathrm{RH}=35 \%$ at temperatures $<353 \mathrm{~K}$. Thus the threshold stress of ESCC would be larger than $0.25 \sigma_{y}$ for these stainless steels. If the stress concentration from a corrosion pit was taken into account, the threshold stress will increase to $0.56 \sigma_{y}$.

(3) The ESCC crack length and crack depth conformed to the double exponential distribution, since the SCC process was dominated by the crack propagation subprocess in the test condition.

\section{References}

1) Japan Stainless Steel Association, "Sutenresu-ko Binran (Stainless Steel Handbook)", Nikkann-kogyo Shinbunsha, pp.1179-1424 (2003).

2) M. Nakahara and K. Takahashi, Proc. JSCE M aterials and Environments 1985, p.217, JSCE (1985).

3) T. Kawamoto, B oshoku-Gijutsu (presently Zairyo-toKankyo) , 37, 30 (1988) 
4) Home Page, Tokyo Electric Power Co. http:/ / www.tepco.co.jp/ cc/ press/ 02112201 -j.htm

5) S. Shoji, N. Ohnaka, Y. Furutani and T. Saitoh, BoshokuGijutsu (presently Zairyo-to-Kankyo), 35, 559 (1986).

6) M. M ayuzumi, T. Arai and K. Hide, Zairyo-to-Kankyo, 52, 166 (2003).

7) JSM S, "Zairyo-kyodo Gaku (M aterials strength)", The Society of M aterials Science, Japan, p.185(2003).

8) M. Mayuzumi, T. Arai, and J. Tani, Chloride Induced Stress Corrosion Cracking of Candidate Canister M aterials in Air, 13th Asian-Pacific Corrosion Conference, 16-21 N ov., Osaka, Japan (2003) .

9) Home Page, Shikoku Electric Power Co., http:// www.yonden.co.jp/ denryoku/ ikata/ press/ indexl.htm.
10) M. Takemoto and T. Shinohara, Proc. Fushoku-Boshoku '85, p.201, JSCE (1985).

11) M. Nishida, "Ouryoku Shuuchuu", M orikita Shuppan Co., pp.526-529(1973).

12) Japan Society of Corrosion Engineering, Souchi-zairyou no Jumyo-yosoku Nyumon, M aruzen (1984)

13) M. Akashi and T. Kawamoto, Boshoku-Gijutsu (presently Zairyo-to-Kankyo), 32, 9 (1983)

14) M. Tokiwai, H. Kimura and H. Kusanagi, Corrosion Science, 25, 837 (1985).

( $M$ anuscript received J uly 22, 2005; in final form October 14, 2005)

\section{要旨}

SUS304L, SUS316L およびSUS304 ステンレス鋼の塩化物応力腐食割れ (ESCC) 特性を 333 K から 353 K の温度範囲，相対湿度 $35 \%$ の条件下で, 海塩粒子を模擬した人工海水を付着させて検討した . 304L ス テンレス鋼に対しては，応力と破断時間の関係を $\sigma(\mathrm{MPa})=-\mathrm{A} \log \left(\mathrm{t}_{\mathrm{f}}[\mathrm{h}]\right)+\mathrm{B}$ の形で定式化した . ここで $A=23.7 T-7020, B=43.7 T-11600$ ( $T$ : 絶対温度) である.負荷応力が $0.2 \%$ 耐力の 0.25 倍の場合, 試験 片表面に微視的な割れさえ認められず，これらのステンレス鋼に対する ESCC のしきい応力は耐力の 0.25 倍より大きいことがわかった . また孔食による応力集中を考慮すれば，この值はさらに大きくなるものと 推定される.さらに統計的な解析結果によればESCC クラック長さおよびクラック深さは, 二重指数分布 に従うことが示唆された

$$
\text { キーワード ステンレス鋼, 外面応力腐食割れ, 塩化物, 海塩粒子, 相対湿度 }
$$

